\title{
A vallásszabadság a dualizmus kori Magyarországon, avagy a jogállami szabályozás megalapozásának kora
}

\section{BÓDI STEFÁNIA ${ }^{1}$}

A tanulmány a vallásszabadság szabályozását tekinti át a dualizmus kori Magyarországon. A dualizmus az átalakulóban lévö magyar társadalom korszaka volt, a cikkböl képet kaphatunk a folyamatban lévö társadalmigazdasági folyamatokról. Bár a vallásszabadságot már 1848-ban is szabályozták, a legjelentösebb törvények 1894 és 1895 során születtek. A vallásszabadság szabályozása kihatott más törvények megalkotására is, igy például az anyakönyvezésröl vagy a házasságról szóló törvények tartalmára, így ezeket a jogszabályokat is bemutatja a szerző. A korszak a bevett és az elismert vallásokat különböztette meg, ezeket részletesen az olvasó elé tárja a tanulmány és a korszak kiemelkedö politikusainak, államférfiainak nézeteit is ismerteti a témakörben. Ebben az idöszakban fejlödtek ki a vallásszabadság jelenlegi körvonalai, a szabadságjog a szocializmus kori elnyomást követöen majd a rendszerváltással nyeri el újra jogállami alapjait.

Kulcsszavak: vallásszabadság, dualizmus, kiegyezés, bevett vallás, elismert vallás, megtűrt felekezetek, katolikus, protestáns, izraelita, unitárius

\section{Freedom of Religion in Hungary in the Age of Dualism, or the Age at which the Rule of Law is Established}

The study reviews the regulation of the freedom of religion in the age of dualism in Hungary. Dualism was the era of the transforming Hungarian society; the article gives a description of the ongoing socio-economic processes. Although freedom of religion was already regulated in 1848, the most significant laws were enacted in 1894 and 1895. The regulation of religious freedom has also influenced the enactment of other laws, such as the content of laws on matrimonial/birth registration or marriage, so these laws are also presented by the author. The period distinguished between the accepted and recognised religions; they are also presented to the reader in detail in the study together with the views of the prominent politicians and statesmen of the period.

1 Habilitált egyetemi docens, Nemzeti Közszolgálati Egyetem Államtudományi és Nemzetközi Tanulmányok Kar Alkotmányjogi és Összehasonlító Közjogi Tanszék, e-mail: bodi.stefania@uni-nke.hu 


\begin{abstract}
During this period, the current outlines of the freedom of religion developed, and after the repressive era of socialism, this freedom restored its foundations of the rule of law with the change of the regime.
\end{abstract}

Keywords: religious freedom, dualism, Austro-Hungarian Compromise, common religion, recognised religion, tolerated confessions, Catholic, Protestant, Hebrew, Unitarian

„Sok kincsekkel áldotta meg a természet hazánkat; de az irigy sors megtagadta tőlünk legszebb áldását, a közértelmet és egyetértést, talán azért, hogy a magyar soha virágzó nagyságra ne emelkedhessék, soha igazán szabad és független ne lehessen. Nem is a külső erőszak fog egykor minket elnyomni, hanem belső egyenetlenség" Deák Ferenc: $A$ vallás ügyében ${ }^{2}$

\title{
1. Bevezetés
}

Tanulmányomban a vallásszabadság érvényesülését és szabályozását kívánom vizsgálni 1867 és 1918 között hazánkban. Ez az a korszak, amikor a jogállami szabályozás későbbi alapjait lerakja az ország, ami óriási fejlődést jelent az adott korban, egyúttal megalapozását a rendszerváltás utáni elveknek. Természetesen a szocializmus időszaka is fellelhető a két korszak között, de ekkor nem beszélhetünk az egyházak támogatásáról, sem jogi, sem anyagi értelemben, a korszak ideológiai hozzáállása nem kedvezett az egyházaknak. A rendszerváltást követően az 1990. évi IV. törvény szólt az egyházakról, ezt a szabályozást váltotta föl a jelenleg hatályos, de elfogadása óta módosított, jóval differenciáltabb szabályozást tartalmazó 2011. évi CCVI. törvény. Hazánk a rendszerváltás óta több nemzetközi szervezethez is csatlakozott, így az Európa Tanácshoz 1990-ben és az Európai Unióhoz 2004-ben. Mindkét szervezet emberi jogi dokumentumai rögzítik a vallásszabadságot, az Európa Tanács az Emberi Jogok Európai Egyezményében kimondja, hogy

„mindenkinek joga van a gondolat-, a lelkiismeret- és vallásszabadsághoz; ez a jog magában foglalja a vallás vagy meggyőződés megváltoztatásának szabadságát, valamint a vallásnak vagy meggyőződésnek mind egyénileg, mind együttesen, mind a nyilvánosság előtt, mind a magánéletben istentisztelet, oktatás és szertartások végzése útján való kifejezésre juttatásának jogát. A vallás vagy meggyőződés kifejezésre juttatásának szabadságát csak a törvényben meghatározott, olyan korlátozásoknak lehet alávetni, amelyek egy demokratikus társadalomban a közbiztonság,

2 Deák Ferenc: A vallás ügyében (I. kötet, 1829-1847). In Deák Ferencz beszédei. Budapest, FranklinTársulat, 1882-1886. 
a közrend, közegészség vagy az erkölcsök, illetőleg mások jogainak és szabadságainak védelme érdekében szükségesek.”

Az Európai Unió szerint is mindenkinek joga van a gondolat-, a lelkiismeret- és a vallásszabadsághoz.

„Ez a jog magában foglalja a vallás vagy a meggyőződés megváltoztatásának szabadságát, valamint a vallásnak vagy meggyőződésnek mind egyénileg, mind együttesen, mind a nyilvánosság előtt, mind a magánéletben, istentisztelet, oktatás és szertartások végzése útján való kifejezésre juttatását. A katonai szolgálat lelkiismereti okból történő megtagadásához való jogot az e jog gyakorlását szabályozó nemzeti törvények szerint el kell ismerni."

A nemzetközi emberi jogi szervezetek a vallási sokszínűség, tolerancia és a demokrácia fogalmát összekapcsolják jogértelmezéseikben, az egyes vallások és felekezetek elismerése azonban, láthatjuk majd, hogy hazánkban (is) igen hosszú utat tett meg. Az is elmondható, hogy az államegyház, az állam konkrét vallás iránti elkötelezettsége nem felel meg az Európa Tanács és az Európai Unió által felfogott vallásszabadság eszméjének.

Bevezetésként utalunk rá, hogy a vallásszabadság hazánkban jelenleg biztosított, az egyházak a rendszerváltással visszanyerték közjogi státusukat, és visszakapták korábban elvett vagyontárgyaikat. Magyarországon felekezeti egyenjogúság van, az állam semleges, nem elkötelezett egyetlen vallás irányában sem. Az állam együttműködésre törekszik az egyházakkal. Az itt elmondottaknak nem mond ellent, hogy Magyarország Alaptörvénye kiemeli a Nemzeti Hitvallásban a keresztény vallást, amelynek nemzetmegtartó erejét hangsúlyozza, hiszen a magyar történelemben ez a vallás volt meghatározó a kezdetektől fogva. A vallás- és lelkiismereti szabadság alapvető emberi jog, és klasszikus szabadságjog, amelynek értelmében mindenki szabadon megválaszthatja vallását, azt módosíthatja, illetve szabadon kinyilváníthatja egyénileg vagy másokkal közösen. A vallásgyakorlás Magyarországon a Magyar Honvédség, a büntetés-végrehajtási intézmények és az egészségügyi intézmények (kórház) keretei között is biztosított. „Az alkotmányokban a vallásszabadság következetesen a lelkiismereti szabadsággal együtt kerül deklarálásra, aminek nem csak történeti okai vannak, hanem e jogok tartalmukban is összekapcsolódnak. A lelkiismeret fogalma ugyanakkor jogilag nem meghatározott." ${ }^{5}$ Látni fogjuk, hogy hosszú és rögös utat tett meg a vallásszabadság hazánkban a mostani állapotig, a cikkben tárgyalt korszak pedig jelentős változásokat hozott az egyházak életében és a hívek jogaiban egyaránt.

3 1993. évi XXXI. törvény az emberi jogok és az alapvető szabadságok védelméről szóló, Rómában, 1950. november 4-én kelt Egyezmény és az ahhoz tartozó nyolc kiegészítő jegyzőkönyv kihirdetéséről, 9. cikk.

4 Az Európai Unió Alapjogi Chartája, 10. Cikk.

5 Balogh Zsolt - Gárdos-Orosz Fruzsina: Vallásszabadság és lelkiismereti szabadság. In Halász Iván (szerk.): Alkotmányjog. Budapest, Dialóg Campus, 2018. 243. 


\section{A vallásszabadság szabályozása az 1867-es kiegyezéstől 1895-ig}

A dualizmus időszakát Magyarországon az 1867-es kiegyezéstől 1918-ig számítjuk. Ez a korszak rengeteg változást idézett elő, valójában az átalakuló magyar társadalom időszakát látjuk ekkoriban is. A kiegyezésről szóló 1867. évi XII. törvénycikk ${ }^{6}$ közös ügyként határozta meg Ausztria és Magyarország között a külügyet, a hadügyet és az ezek fedezésére szolgáló pénzügyet. ${ }^{7}$ Ezenkívül közös volt még az uralkodó személye. Természetesen a magyar kormány is működött ekkoriban, vagyis az állam életét Bécsből és Budapestről egyaránt irányították. A Monarchia egyébként úgynevezett reálunió volt alkotmányos jogállása szerint, amely utal arra, hogy a közös ügyeken kívül az uralkodó személye is közös volt, vagyis ez egy elég szoros formája az államkapcsolatoknak. Ausztria és Magyarország kapcsolatában az I. világháború újabb megpróbáltatást teremt, s ez elvezet a birodalom felbomlásához. A Monarchia végét jelenti majd, amikor az eckartsaui nyilatkozatban 1918. november 13-án IV. Károly magyar király lemond uralkodói jogairól.

Az osztrák-magyar kiegyezést követően hamarosan megszületett a horvát-magyar kiegyezési törvény is, amely rendezni kívánta Horvátország közjogi helyzetét. Horvátország egyházszervezetileg 1853-ban vált önállóvá. ${ }^{8}$ Ez az időszak az emberi jogi törvények megszületésének időszaka is, noha bőven van még tennivaló a jogok kiteljesedését illetően. A nők választójoggal még nem rendelkeznek ebben a korszakban. A polgárosodás, az ipari fejlődés kezdetét veszi, de az ország még magán viseli a feudális maradványokat a jobbágyfelszabadítás után is. A parasztság vegyes képet mutat, a legszegényebb emberektől a módos parasztokig. Soknemzetiségű államról van szó, olyan sok nemzetiséggel a dualista államban, hogy több koncepció is született ekkoriban a népek egyben tartására. ${ }^{9}$ Ez a korszak egyúttal a nacionalizmus éledésének időszaka is. A dualizmus időszakának egyik nagy problémája az átalakuló gazdaság és társadalom mellett tehát a nemzetiségi kérdés volt, amelynek rendezésére 1868-ban megszületett a XLIV. törvény a nemzetiségekről. A törvény a vallások és felekezetek kérdését érintőlegesen érinti csupán, az egyházi nyelvhasználat vonatkozásában. Bár a törvény a magyar nyelvet írja elő főszabályként egyházi ügyekben is, a törvény szerint községi és egyházi gyűlésekben a szólás jogával bírók szabadon használhatják anyanyelvüket és saját nyelvükön adhatnak be beadványokat saját községükhöz, egyházi hatóságukhoz és törvényhatóságukhoz. A korszak a politikai pár-

6 1867. évi XII. törvénycikk a magyar korona országai és az Ő Felsége uralkodása alatt álló többi országok között fenforgó közös érdekü viszonyokról, s ezek elintézésének módjáról.

7 8. \$ A pragmatica sanctióból folyó közös és együttes védelemnek egyik eszköze a külügyek czélszerü vezetése. 9. \$ A közös védelemnek másik eszköze a hadsereg s az arra vonatkozó intézkedések, egy szóval: a hadügy. 16. $\$$ A pénzügyet annyiban ismeri a magyar országgyülés közösnek, a mennyiben közösek lesznek azon költségek, melyek a fenebbiekben közöseknek elismert tárgyakra forditandók.

8 Katus László: Vallások, egyházak. In Egyháztörténet. Haza és haladás a reformkortól a kiegyezésig (1790-1867). Budapest, Enciklopédia Humana Egyesület, 2000.

9 Ezzel a kérdéssel, vagyis a kelet-közép-európai népek együttélésével még jóval a Monarchia kora után is foglalkoztak, lásd például Bibó István nézeteit. 
tok formálódásának időszaka is, a kormánypártok és az ellenzék nézeteiben a meghatározó sarokpont a Monarchiához való viszony volt.

A továbbiakban a vallásszabadság tárgyában hozott törvénycikkeket időrendben tekintjük át. Bár 1848. nem tartozik a tárgyalt időszakhoz, ekkor született egy olyan jelentős törvény az 1848. évi XX. törvénycikk a vallásszabadságról, amelyre a később született törvények folyamatosan visszautalnak, ezért nem nélkülözhetjük a tárgyalását. A törvény értelmében a törvényesen bevett minden vallásfelekezetekre nézve különbség nélkül tökéletes egyenlőség és viszonosság állapíttatik meg, a bevett vallásfelekezetek iskoláiba ,járhatás” pedig valláskülönbség nélkül mindenkinek kölcsönösen megengedett. A minisztérium rendelkezni fog arról, hogy a bevett vallásokat követő katonák saját vallású tábori lelkészekkel láttassanak el. A törvény egyúttal az unitária vallást törvényes bevett vallásnak nyilvánította.

Széchenyi István a vallás dolgában többször is felszólalt és vallási türelemre intett. Ö maga hithủ katolikus neveltetésben részesült, de nem volt a merev formaságok embere vallási ügyekben. Meglátása szerint „nincs arról szó, hogy az istennek akármi teremtését jogokból kirekeszszük, mert felfogásom és vallásos érzelmem szerint azt szeretném, hogy e hazában minden ember, ki az isten képére van alkotva, egyenlő jogokkal birjon és egyenlő terheket viseljen; és bár mondhatná mindenki valláskülönbség nélkül: nekem is van itt hazám!".10

Meg kell említenünk, 1855-ben a Szentszék és az Osztrák Császárság között megkötött konkordátum megszületését,

„a római katolikus egyháznak meghatározó szerepe volt abban, hogy a birodalom nemzetiségeit összefogja, tekintet nélkül nyelvi, történelmi vagy etnikai különbségekre. A magyar és az osztrák egyház egységesítésére a római Szentszéknek volt egyedül joga, hiszen a katolikus egyház szerkezetét tekintve elvileg nem nemzeti egyházakból, hanem püspökségekből állt”."11

A konkordátumot 1855. augusztus 18-án fogadták el és november 5-én egy császári pátensben lett kihirdetve. A konkordátum a katolikus egyház megerősödését vonta maga után az oktatásban és az egyház irányításában. A konkordátum egyebekben „36 pontban szabályozta a katolikus egyház helyzetét a Habsburg Birodalomban, tartalmazza a lemondást a placetum regiumról, azaz a királyi tetszvényjogról, miszerint csak engedéllyel lehet kihirdetni a Római Kúriától érkező rendelkezéseket. További rendelkezései, hogy ismét visszatérhetett az országba a jezsuita rend, a katolikus iskolákat teljes egészében közvetlenül egyházi felügyelet alá helyezte, a vegyes házasság-

10 Gróf Széchenyi István beszédei II. kötet. Budapest, Athenaeum, 1887. 355.

11 Niklai Patrícia Dominika: Az 1855. évi osztrák konkordátum - ahogyan az egyház látta. Ars Boni, 2015. október 11 . 
ban élő katolikusok családjogi ügyeit az egyházi bíróság elé utalta, biztosította az egyházi javak autonóm igazgatását".

Ezt követően 1859-ben a protestáns pátens is megjelent, egy császári rendelet, amely korlátozta a protestáns egyházak szabadságát. Ferenc József elrendelte 1860 januárjában, hogy hirdessék ki a pátenst az egyházak szószékeiről is. Végül 1860 májusában hatálytalanították..$^{13}$

Meghatározó jelentőségű a korszakban a zsidóság szempontjából, az 1867. évi XVII. törvénycikk az izraeliták egyenjogúságáról polgári és politikai jogok tekintetében, amelynek értelmében az ország izraelita lakosai a keresztény lakosokkal minden polgári és politikai jog gyakorlására egyaránt jogosítottaknak nyilváníttatnak, minden ezzel ellenkező törvény, szokás vagy rendelet, ezennel „megszüntettetik.” A törvények eredményeként egyre több zsidó család települ majd le Magyarországon, amely hozzájárul a polgárosodás folyamatához.

Ezután az 1868. évi IX. törvénycikk látott napvilágot, amely tartalmazta, hogy a görögkeleti vallásúak jogosítva vannak egyházi, iskolai és ezekre vonatkozó alapítványi ügyeiket, az ország törvényeinek korlátai között önállóan intézni. Megjegyezzük, hogy a törvényalkotó már 1790-1791-ben rendelkezett arról, hogy a vallás hívei más honlakosok módjára, Magyarországban és a kapcsolt részekben jószágok szerzésére $\mathrm{s}$ birtoklására és minden hivatal viselésére képesek legyenek..$^{14} \mathrm{~A}$ rendelkezést úgy értelmezik, hogy ezzel a görögkeleti vallás is elnyerte a bevett státust.

Az 1868. évi LIII. törvénycikk a törvényesen bevett keresztyén vallásfelekezetek viszonosságáról rendelkezve kimondta, hogy „mindenkinek szabadságában áll más hitelfelekezet kebelébe, $\mathrm{s}$ illetőleg más vallásra áttérni, áttérni annak szabad, a ki életkora 18 évét már betöltötte.” Az áttérési szándékról két ízben kellett nyilatkozni, „az áttértnek áttérése utáni minden cselekvényei azon egyház tanai szerint ítélendők meg, melybe áttért, $\mathrm{s}$ az általa elhagyott egyház elvei reá nézve semmiben sem kötelezők. Egyik vallásfelekezetnek tagjai sem kötelezhetők arra, hogy más vallásfelekezetbeliek egyházi szertartásait és ünnepeit megtartsák.” Tartalmazta, hogy „vegyes házasságok bármelyik fél papja előtt érvényesen köthetők." A törvény értelmében a vegyes házasságokból származó gyermekek közül a „fiak atyoknak s a leányok anyjoknak vallását követik". A törvény már lehetővé tette a hadseregnél és a kórházakban e jog gyakorlását, és a temetőkben nem gátolta a vallás alapján a temetkezést, vagyis a különböző vallásfelekezetek tagjai vegyesen és akadálytalanul temetkezhettek. A törvény a korszak vallásügyi miniszterének, Eötvös Józsefnek a nevéhez füződik, aki másodszorra vitte a vallásügyi tárcát. Eötvös igyekezett a felekezetek számára a legnagyobb szabadságot biztosítani, úgy vélte a kereszténység a szabadság vallása, amit minden keresztény egyháznak meg kell adni, az egyház szabadsága az állam rendíthetetlen biztosíté-

12 Balogh Margit: Egyházak és felekezetek. 19. századi előzmények. In Kollega Tarsoly István (föszerk.): Magyarország a XX. században II. kötet. Szekszárd, Babits, 1997b. 287.

13 Magyar Katolikus Lexikon.

14 1790/91. évi XXVII. törvénycikk a görög nem-egyesült vallásuakról. 
ka, véleménye szerint maga a zsidóság is egészen csatlakozott erkölcstan tekintetében a kereszténység alapelveihez. ${ }^{15}$

1872-től Trefort Ágoston ${ }^{16}$ lesz a vallásügyi miniszter, aki amerikai és angol példákat alapul véve hitt a vallás szabadságában. Azon elmélkedik, vajon angolnak vagy amerikainak kell-e lenni ahhoz, hogy valaki polgári szabadságjogokat élvezhessen. Úgy véli, a vallási üldözések az emberiség legszomorúbb eseményei közé tartoznak, szerinte a humanitás leginkább e szabadságjogban mutatkozik meg. Az állam és az egyház elválasztása mellett foglalt állást, problémának tartja, hogy a tudomány a vallástól elszakadt.

Az 1885. évi VII. törvénycikk a fórendiház szervezetének módositásáról rendelkezett és kibővítette azt az egyházi méltóságokkal. Legjelentősebb változás, hogy bekerültek a protestáns egyházak és az unitárius egyház püspökei, illetve főgondnokai a főrendiházba. Mindezek alapján a Főrendiház tagjai voltak, akik: a) örökös jogon voltak azok, b) akik az általuk viselt méltóság vagy hivatal révén, c) akiknek Ő Felsége a király által élethossziglan ${ }^{17}$ lett kinevezésük, d) akiknek a „Horvát-Szlavonországok” gyűlése által az 1881:XV. törvénycikk értelmében választás következtében volt a förendiházban ülési és szavazati joga. Örökös jogon voltak tagjai a förendiháznak: a felséges uralkodóház teljes korú főhercegei, a magyar förendiházban a tagságra eddig jogosított, illetve az erdélyi nagyfejedelemségben annak Magyarországgal történt egyesítése előtt, a magyar királyok által grófi vagy bárói címet nyert családok 24 . évüket betöltött, nagykorú férfi tagjai, akik egyedül vagy feleségük és kiskorú gyermekeik vagyonát is odaszámítva a magyar állam területén olyan földbirtoknak tulajdonosai vagy életfogytiglan haszonélvezői voltak, amelynek állami földadója legalább 3000 forintot tett ki osztrák értékben. Tagok azon leszármazásuknál fogva magyar állampolgárok és egyenes leszármazás útján törvényes fiú-utódaik, akiknek a megfelelő (hercegi, grófi, bárói) címen kívül Ő Felsége a király az örökös förendiházi tagság jogát is külön adományozta. Az általuk viselt méltóság vagy hivatal alapján voltak tagjai a förendiháznak: az ország zászlósai és a pozsonyi gróf, a két koronaőr, a fiumei kormányzó, a királyi Curia elnöke, másodelnöke és a budapesti királyi ítélötábla elnöke.

„Ugyancsak a méltóságuk, illetőleg hivataluknál fogva tagjai a főrendiháznak: a magyar szent korona országainak latin és görög szertartású római katolikus egyháznagyai, vagyis: Magyarország herczegprimása és a többi érsekek, továbbá a megyés püspökök és szintén a magyar király kinevezésétől függő nádorfejérvári és tinnin-i felszentelt püspökök, a pannonhalmi főapát, a jászói prépost és az aurániai perjel; a görög-keleti egyház egyháznagyjai: a szerb patriárka, a román

15 Eötvös József: A vallás befolyása az államra. In Eötvös József: $A$ XIX. század uralkodó eszméinek befolyása az Államra II. kötet. 10. és Ötödik könyv, XII. fejezet, 1851. 230-236. A szöveget gondozta Oltványi Ambrus.

16 Trefort Ágoston: Emlékbeszédek és tanulmányok. Budapest, A M. Tud. Akadémia KönyvkiadóHivatala, 1881. 120, 130, 131, 133.

17 Az élethossziglani tagok összes száma pedig az 50-et túl nem haladhatja. 
metropolita és a megyés püspökök; az evangélikus-református és ágostai hitvallású evangélikus egyháznak hivatalban legidősebb három-három püspöke; továbbá az evangélikus-református egyháznak hivatalban legidősebb három főgondnoka; az ágostai hitvallású evangélikus egyháznak egyetemes főfelügyelője és hivatalban legidősebb két kerületi felügyelője; az unitárius egyháznak hivatalban idősebb egyik elnöke, azaz vagy püspöke vagy fögondnoka."18 "A kortársak és a történeti irodalom nagy része is az arisztokrácia politikai hatalomvesztésének tekinti az adott reformot [...] az új főrendiház azonban továbbra is arisztokrata intézmény maradt, egyes kérdéseknél továbbra is a római katolikus egyház képviselőinek karakterisztikus álláspontja érvényesült." ${ }^{19}$

Elhíresült a 1894. évi XXXI. törvénycikk is, amely a házassági jogról címet viselte. A törvény a kötelező polgári házasságról rendelkezett és kimondta, hogy a házasságot polgári tisztviselő előtt kell megkötni. Az a lelkész vagy vallási szertartás teljesítésére jogosított más személy, aki egyházi összeadásnál eljár, mielőtt a felek igazolták volna, hogy a házasságot a polgári tisztviselő előtt megkötötték, vétséget követ el és ezer koronáig terjedhető pénzbüntetéssel büntetendő; ismétlés esetében a cselekmény két hónapig terjedhető fogházzal és ezer koronáig terjedhető pénzbüntetéssel büntetendő. ${ }^{20} \mathrm{Nem}$ volt büntethető azonban a cselekmény, ha az egyházi összeadás az egyik félnek közeli halállal fenyegető betegsége miatt történt. A törvény egyúttal a vegyes házasságokat is engedélyezte, hiszen a házassági akadályok sorában nem említette a felek eltérő vallását.

Az 1894. évi XXXII. törvénycikk a gyermekek vallásáról rendelkezett és kimondta, hogy a bevett vagy törvényesen elismert különböző vallásfelekezethez tartozó házasulók, házasságuk megkötése előtt megegyezhetnek arra nézve, hogy gyermekeik az „atya” vagy az anya vallását kövessék, illetőleg abban neveltessenek. A megegyezés csak akkor volt érvényes, ha királyi közjegyző, királyi járásbíró, polgármester vagy föszolgabíró előtt a megállapított alakszerủségek mellett jön létre. Megegyezés hiánya esetén a gyermekek szülőik vallását nemük szerint követik. A törvénytelen gyermekek pedig az anyjuk vallását követték. Ehhez kapcsolódott egy miniszteri rendelet, amely a törvény végrehajtási rendelete volt, a vallás- és közoktatásügyi miniszternek a 1675/1895. eln. számú rendelete, és kimondta, hogy azok, akik a bevett vagy törvényesen elismert vallásfelekezetek egyikéhez sem tartoznak, a hivatkozott rendelet értelmében gyermekeik vallása és nevelése tekintetében is azon vallásfelekezet híveinek tekintendők, amelyhez azelőtt tartoztak.

Az 1894. évi XXXIII. törvénycikk az állami anyakönyvekröl rendelkezett és tartalmazta, hogy a születési anyakönyvnek tartalmaznia kell a szülők és a gyermek vallását, a házassági és a halotti anyakönyvnek pedig az érintettek vallását.

18 1885. évi VII. törvénycikk a fơrendiház szervezetének módosításáról, I. fejezet.

19 Boros Zsuzsanna - Szabó Dániel: A főrendiház. In Boros Zsuzsanna - Szabó Dániel: Parlamentarizmus Magyarországon (1867-1944). Parlament, pártok, választások. Budapest, ELTE Eötvös, 2014. 1894. évi XXXI. törvénycikk a házassági jogról, 123. \$. 
Vallási kérdésekben a kor nagyjai is sokszor kinyilvánították véleményüket, így a felvilágosult szabadelvű nézeteket valló Kossuth Lajos is, aki protestáns neveltetésben részesült. Kossuth nem ellenezte a misék magyar nyelven történő lefolytatását, és nem gondolkodott éles felekezeti elválasztásban, ahogy Széchenyi és Deák sem. Foglalkozott a zsidóság egyenjogúsításával is. Ellenezte az államvallást és elsősorban a nemzeti egységet tartotta szem előtt vallási kérdésekben is. ${ }^{21}$

\section{A vallásszabadság szabályozása 1895-1918 között}

A legnagyobb hatású változásokat ezt követően az 1895-ben elfogadott törvények jelentik a korszakban. Az 1895. évi XLII. törvénycikk az izraelita vallásról rendelkezett és kimondta, hogy az izraelita vallás törvényesen bevett vallásnak nyilváníttatik. Tartalmazta továbbá, hogy lelkész (rabbi) és hitközségi elöljáró az izraelita felekezetnek csak olyan tagja lehet, aki magyar állampolgár, és aki képesítését Magyarországon szerezte. A törvény végrehajtási rendelete a vallás- és közoktatásügyi m. kir. minister 1895. évi 2532. eln. számú rendelete volt, amely a valamennyi törvényhatóság közönségéhez címet viselte.

Az 1895. évi XLIII. törvénycikk a vallás szabad gyakorlásáról jelentős mérföldkőnek tekinthető, mert ez a törvény vezeti be az elismert vallás kategóriát. Vagyis a bevett és elismert ${ }^{22}$ vallásokat különböztetjük meg innentöl. A törvény értelmében vallási hite vagy egyházi szabályai senkit sem menthetnek föl törvényen alapuló bármely kötelesség teljesítésétől. Lehetővé tette valamely vallásfelekezetből a kilépést, vagy valamely vallásfelekezetbe a belépést, a törvényekben megállapított feltételek alatt. Bevett vallásnak ${ }^{23}$ minősült ekkoriban tehát a latin, a görög és az örmény szertartású katolikus (már I. Istvántól kezdve), az evangélikus református (1791-től), az ágostai hitvallású evangélikus (1791-től), a görög-keleti szerb és görög-keleti román (1791-től), ${ }^{24}$ valamint az unitárius egyházak (1848-tól) és hívek - nemkülönben az izraelita (1895-től).

21 Lásd részletesen Zakar Péter: Kossuth Lajos egyházpolitikai elvei a reformkorban. Acta Academiae Paedagogicae Agriensis Nova Series: Sectio Historiae, (2002), 129-141.

22 Ilyenek voltak az 77.092/1905. VKM. rendelettel elismert baptista, az 1916. XVII. tc.-be iktatott iszlám vallás, „1. Az elismert vallásfelekezetek ingatlanszerzési képessége korlátozott volt, a bevetté nem. 2. A bevett felekezetek egyházi adóit közigazgatási úton behajtották, az elismertekét nem. 3. A bevett vallásfelekezetek fegyelmi határozataik végrehajtásához állami segítséget igényelhettek, az elismertek nem. 4. Új egyházközségek alapítása a bevett egyházak önkormányzati joga volt, elismerteknél ehhez hatósági közreműködés volt szükséges. 5. Elismert felekezetek nem igényelhettek a községtől aránylagos segélyt, a bevett vallásfelekezetek igen. 6. Bevett felekezetek hitoktatóit az állam fizette és egyéb anyagi támogatásban (iskolák) is részesültek stb." Lásd Csizmadia Andor: A vallás- és lelkiismereti szabadság és a felekezetek egyenjogúságának kérdése Magyarországon a dualizmus korában. Jogtudományi Közlöny, 18. (1963), 1. 29-30.

23 „A vallás- és közoktatásügyi m. kir. miniszterium 1887. 2435. sz. a. rendeletet bocsátott ki, melyben a bevett vallás fogalmát következőleg határozza meg: bevett vallás közjogilag a vallásnak törvényes oltalom alá helyezését, jogainak törvényes védelmét és biztosítását jelenti; továbbá, hogy a vallás bevételével az illető hitsorsosok mindenkor bizonyos jogok élvezetében részesülnek."

24 Az 1791. évi XXVII. törvénycikk a görög nem egyesült (ortodox) vallást bevett vallásnak ismerte el. Katus (2000): i. m. 
Kétségkívül a legmélyebb gyökerekkel a katolikus egyház rendelkezett az országban, ennek megfelelően szoros volt az állammal való kapcsolata is. Köztudott, hogy magyar király csak római katolikus lehetett.

Azok az állampolgárok, akik törvényesen elismert vallásfelekezetté kívánnak alakulni: tartoznak legalább egy egyházközség felállítását és fenntartását, továbbá a felekezetükhöz tartozó gyermekeiknek iskolai hitoktatását biztosítani; tartoznak a hitéletre vonatkozó összes rendelkezéseket magában foglaló szervezeti szabályzatot jóváhagyás végett a vallás-és közoktatásügyi miniszternek bemutatni. (Vagyis itt miniszteri jóváhagyás van szemben a törvényi státussal.) Ennek a szabályzatnak tartalmaznia kell a hitelvi, az erkölcsi tanokra, az istentiszteletre és egyéb vallási szertartásra, valamint a tisztviselők és más alkalmazottak felett gyakorolandó fegyelmi szabályokra vonatkozó rendelkezéseket. A jóváhagyás csak akkor volt megtagadható: ha a megalakulni kívánó vallásfelekezet állam- vagy nemzetellenes irányzattal keletkeznék; ha a hitelvek, tanok, istentisztelet és egyéb vallási szertartás, vagy a tervezett szervezet a fennálló törvényekkel vagy közerkölcsiséggel ellentétben állna; ha a már létező és törvényesen bevett vagy elismert vallásfelekezetek valamelyikével azonosak; ha a megalakulni kívánó vallásfelekezet elnevezése faji vagy nemzetiségi jellegű lenne; a már bevett vagy törvényesen elismert vallásfelekezeteket sértené.

„A korabeli nézet az volt, hogy az elismert felekezeteket magánjogi állásúnak, a bevett felekezeteket pedig közjogi, ilyen módon paritásos, azaz egyenértékủ állásúnak tekintették. Az elkülönítés lényegében a hatalomban való részvétel mértékére mutat rá; a magánjogi státus a társadalmi szervezetek szintjére utalja a felekezetet (mely ezáltal vagyonjogi és családi jogi következmények eldöntésére képes), tehát a magánszemélyek egymás iránti kötelezettségeire terjed ki, míg a közjogi státus az állami életben való részvételt teszi lehetővé."25

A harmadik kategória tulajdonképpen az el nem ismert vagy türt felekezetek csoportja volt, amelyeket szektának tekintettek. Idetartoztak a következő vallások:

„[A]z 1910. évi népszámlálás adatai szerint 8086 baptista, 5840 nazarénus, 256 metodista, 757 mohamedán, 145 egyéb vallású, 2322 felekezeten kívüli és 46 ismeretlen vallású lakos élt a Magyar Királyságban, összesen 17452 fö. Ez az összlakosságnak 0,1\%-a. 1918-ig jelentősebb kisegyházak a baptisták, a nazarénusok, az adventisták, a metodisták, a pünkösdi(sta) csoportok és a jehovisták." ${ }^{26}$

A törvény végrehajtási rendelete a vallás- és közoktatásügyi, a belügyi és az igazságügyi m. kir. ministerek 1896. évi 56/V. K. eln. szám alatt kelt rendelete volt.

25 Horváth Attila: A vallásszabadság és az egyházjog története Magyarországon az államalapítástól a II. világháborúig. Hét Hárs, 10. (2011), 3-4. 19.

26 Balogh Margit: A kisegyházak és a magyarországi iszlám. In Kollega Tarsoly (főszerk.) (1997a): i. m. 289. 
A reformtörekvések közepette gyökeret vertek a liberális nézetek, amelyek érvényesültek egyes vallások terén is.

„A 19. században a protestáns teológiában erőteljesen érvényesültek a racionalizmus, majd a liberalizmus eszméi. A század közepén uralkodóvá váló liberális teológia a korszerű természettudomány és a pozitivista történetszemlélet módszereit alkalmazta a hit kérdéseire. Megkérdőjelezték a keresztény dogmatika alaptételeit, s a hitet megfosztották minden természetfeletti vonatkozásától [...] A vallást elsősorban észhitként és morálként, egyfajta erkölcsi, szellemi magatartásként értelmezték." 27

A református egyház követői a második legnagyobb csoportot alkották a magyar történelem során, ez nem változott az 1800-as évek óta. Az evangélikusok aránya viszont lecsökkent a korábbi 7-8\%-ról napjainkra. Bár mind az evangélikus, mind a református a protestantizmus keretei közé tartozik, híveik számában jelentős eltérés tapasztalható. A keresztény egyházak már a reformáció során elváltak a katolikus egyháztól, és kialakult annak luteránus (evangélikus) és kálvini (református) irányzata. Magyarországon Debrecen lett a református egyház egyik fellegvára, 1849 áprilisában például az evangélikus Kossuth a Debreceni Nagytemplomban hirdette ki az általa szövegezett Függetlenségi Nyilatkozatot. ${ }^{28}$ A vallás ügyével többször foglalkozott a haladó nézeteket valló, katolikus Deák Ferenc is parlamenti beszédeiben, amelyekből kirajzolódik, hogy nem volt egyetértés a képviselők között a kérdésben, a kérdés tárgyalását többször félre is kellett tenni. Deák Ferenc utolsó beszédét is egyházpolitikai kérdésben tartotta, 1873-ban. Beszédében hangsúlyozta, hogy az állam és az egyház kapcsolata egész Európában a legnehezebb kérdések közé tartoznak, kifejezésre juttatta azt a gondolatát, hogy az állam ne, vagy minél kevesebbet avatkozzék az egyházak belügyeibe, és csak akkor és annyiban, amennyiben a státus fönntartása a beavatkozást szükségessé teszi. ${ }^{29}$

Tisza István gróf a dunántúli református egyházkerület rendes közgyủlésén hoszszabb beszédet mondott, amelyben a szekularizáció és a felekezetek egymás elleni küzdelme ellen foglalt állást és úgy fogalmazott, hogy „ne intézzünk más felekezet viszonyai ellen olyan kirohanást, amely valóban a felekezeti küzdelem szinével bir” ${ }^{30}$

A katolikus Apponyi Albert gróf vallás- és közoktatásügyi miniszter annak a reményének adott hangot, hogy az evangélikus és református papok elégedettek lesznek

27 Katus (2000): i. m.

28 Lásd: www.reformatus.hu/egyhazunk/tortenetunk/

29 Deák Ferenc: Képviselőházi beszéd az állam és egyház viszonyáról Pest, 1873. június 28. A dualizmus évei, 1869-1873. In Deák Ferenc: Válogatott politikai írások és beszédek II. kötet, 1850-1873.

30 Kútfők. 304. szám. A Református Papi Kongresszus állásfoglalása az 1848: XX. T.-Cz. végrehajtása tárgyában és gróf Apponyi Albert vallás és közoktatásügyi miniszter nyilatkozata és Tisza István beszéde ugyanebben az ügyben. Magyar-Zsidó Szemle, 24. (1907), 2. 395. 
az 1848-as törvény hozadékaival, a felekezeti egyenjogúsággal és nem lesznek további akcióik. ${ }^{31}$

Elmondható a korszakot elemezve, hogy a katolikus vallásúak többségben voltak végig a kiegyezés kori Magyarországon, ez a helyzet az 1800-as évektől folyamatosan jellemző, a 20. század elejét is beleértve. Míg több helyen arról lehet olvasni, hogy a papság fóuri életmódot folytatott, addig az egyház haladó szellemét a katolikus folyóiratokban villantotta meg, amelyekben igyekezett az egyház nevelési, oktatási, politikai, irodalmi és európai hitéleti kérdésekkel foglalkozni. A katolikus hit terjesztésének fontos eszköze volt tehát a katolikus sajtó, amely már az 1900-as évek elején jelen volt Magyarországon. Bár nem célunk a korabeli vallási megoszlás elemzése, utalunk rá, hogy bár még mindig többségben van a katolikus hívők aránya, az jelentősen lecsökkent napjainkra. Természetesen mára jelentősen nőtt az ateisták aránya is, és sokan nem kívánnak nyilatkozni $(27,2 \%)$ vallási hovatartozásukról. A népesség felekezeti hovatartozásának változásait hazánkban alább az 1., 2., 3. ábra szemlélteti.

A görögkeleti (ortodox) vallásúak aránya 13-15\% körül mozgott a kiegyezéstől a 20. század elejéig. ${ }^{32} \mathrm{Ez}$ volt a harmadik legnagyobb vallás, de mára jelentősen lecsökkent a hívek aránya. Az ortodox kereszténység a keleti és a nyugati kereszténység közti egyházszakadással alakult ki. Nem azonos a görög katolikussal. Elsősorban a volt Jugoszlávia utódállamaiban elterjedt napjainkban, Romániában, Bulgáriában és Oroszországban is.

A zsidók helyzetét egy korábbi törvénycikk rendezte a korszakban, amely továbbra is hatályban volt, ez alapján „Magyarország és kapcsolt részei határain belül élő zsidók az összes szabad királyi városokban és más helységekben (ide nem értvén a királyi bányavárosokat) azon állapotban, melyben az 1790. évi január elsején voltak, megmaradhatnak, és ha abból netalán kizavartattak volna, visszahelyeztessenek". ${ }^{33}$ A jogalkotó igyekezett alkalmazkodni a vallások sajátosságaihoz, ezt mutatja, hogy a vallásügyi miniszter rendeletet adott ki a középiskolai izraelita tanulóknak a szombat-napokon és a többi zsidó-ünnepnapokon az írás és rajzolás alól való fölmentése tárgyában. ${ }^{34} \mathrm{~A}$ korabeli magyar zsidóság jelentősen hozzájárult a kultúra, a kereskedelem és a gyáripar fellendüléséhez.

Az unitárius vallás követői „egyistenben” hisznek, szemben a Szentháromságot valló irányzatokkal. A reformáció során keletkezett irányzat, amely Angliában és az Egyesült Államokban jelentős gyökerekkel rendelkezik. Erdélyben jelentősebb bázisa volt, mint nálunk, elsősorban innen terjedt el a reformkorban Magyarországon.

31 „Sajnálnám, ha a jóhiszemű elemek engednék magukat felhasználni sötét hatalmak által, amelyek csak azért, hogy Magyarországon a politikai konszolidácziót lehetetlenné tegyék, semmitől sem riadnak vissza, még attól sem, hogy a felekezeti békét, amelyet éppen most szilárd alapokra akarok fektetni, reménytelenül összekuszálják." Kútfők. 304. szám (1907): i. m. 394.

32 Balogh Margit: Egyházak a dualizmus korában. Egyházak és felekezetek. In Kollega Tarsoly (föszerk.) (1997c): i. m. 289.

33 1790/91. évi XXXVIII. törvénycikk.

34 A vallás- és közoktatásügyi magyar kir. ministernek 55.711/1892. szám alatt valamennyi tankerületi kir. főigazgatósághoz intézett rendelete. 
1. táblázat: A vallások megoszlása 1868-ban hazánkban

\begin{tabular}{|l|l|l|l|l|l|}
\hline $\begin{array}{l}\text { római } \\
\text { katolikusok }\end{array}$ & ortodoxok & $\begin{array}{l}\text { refor- } \\
\text { mátusok }\end{array}$ & $\begin{array}{l}\text { evan- } \\
\text { gélikusok }\end{array}$ & izraeliták & unitáriusok \\
\hline $57,5 \%$ & $15,2 \%$ & $14,9 \%$ & $8 \%$ & $4 \%$ & $0,4 \%$ \\
\hline
\end{tabular}

Forrás: Balogh (1997c): i. m. 289.

2. táblázat: A vallások megoszlása hazánkban 1910-ben

\begin{tabular}{|l|l|l|l|l|l|}
\hline $\begin{array}{l}\text { római } \\
\text { katolikusok }\end{array}$ & $\begin{array}{l}\text { refor- } \\
\text { mátusok }\end{array}$ & ortodoxok & $\begin{array}{l}\text { evan- } \\
\text { gélikusok }\end{array}$ & izraeliták & unitáriusok \\
\hline $60,3 \%$ & $14,3 \%$ & $12,8 \%$ & $7,1 \%$ & $5 \%$ & $0,4 \%$ \\
\hline
\end{tabular}

Forrás: Balogh (1997c): i. m. 289.

3. táblázat: A lakosság vallási megoszlása 2011-es népszámlálás alapján hazánkban

\begin{tabular}{|l|l|l|l|l|l|l|l|l|l|}
\hline $\begin{array}{l}\text { kato- } \\
\text { liku- } \\
\text { sok }\end{array}$ & $\begin{array}{l}\text { nem } \\
\text { vála- } \\
\text { szol }\end{array}$ & $\begin{array}{l}\text { nem } \\
\text { vallá- } \\
\text { sos }\end{array}$ & $\begin{array}{l}\text { refor- } \\
\text { mátu- } \\
\text { sok }\end{array}$ & $\begin{array}{l}\text { evan- } \\
\text { géli- } \\
\text { kusok }\end{array}$ & $\begin{array}{l}\text { Hit } \\
\text { Gyüle- } \\
\text { kezete }\end{array}$ & $\begin{array}{l}\text { bap- } \\
\text { tista }\end{array}$ & $\begin{array}{l}\text { budd- } \\
\text { hista }\end{array}$ & $\begin{array}{l}\text { izrae- } \\
\text { lita }\end{array}$ & $\begin{array}{l}\text { unitá- } \\
\text { rius }\end{array}$ \\
\hline $39 \%$ & $27,2 \%$ & $18,2 \%$ & $11,6 \%$ & $2,2 \%$ & $0,2 \%$ & $0,2 \%$ & $0,1 \%$ & $0,1 \%$ & $0,1 \%$ \\
\hline
\end{tabular}

Forrás: a KSH adatai alapján: www.ksh.hu/nepszamlalas/tablak_vallas

A korabeli törvényekből érezhető az állam térnyerése az egyházakkal szemben, az átalakuló polgárosodó magyar társadalom szellemisége, amely felvilágosult gondolatokat is magában hordozott, azáltal például, hogy a vallások egyenjogúsítását fokozatosan kibontakoztatta. Nőtt az értelmiségi réteg aránya. De ez a világ ugyanakkor még a feudalizmus maradványait is magán viselő korszak Magyarországon, az arisztokrácia nagy részét a földbirtokos réteg alkotja. Jelen van a dzsentriréteg is, (kisebb) földjét vesztett nemesi középréteget jelent, amely ragaszkodva korábbi életszínvonalához, hivatali, értelmiségi vagy katonai pályára kényszerült, őket örökíti meg Mikszáth Kálmán több múvében. „Az állam és az egyházak viszonyát a kor színvonalán és kívánalmainak lehetséges figyelembevételével rendezték tehát, s távolról sem célozták meg az egyházak szerepének háttérbe szorítását. A vallások áldásos társadalmi jelenléte a hivatalos körök gondolkodásában kívánatos és támogatandó ügy volt.” ${ }^{35}$ A korabeli polgárosodás folyamata jelentette a gazdaság modernizálódását, ugyanakkor a polgárosodás életformát és értékrendet is jelentett. A folyamatban nemcsak az értelmiség

35 Horváth (2011): i. m. 18. 
és a nemesség vett részt, de a kisiparosok, kereskedők is a polgári réteget jelentették. Ennek megfelelően kis, közép- és felső polgári osztályokat különböztettünk meg.

A századfordulótól 1918-ig nem történt annyi jelentős változás, mint korábban, drasztikus váltást ugyanis a szocializmus hoz majd az egyházak életében. Napvilágot látott néhány törvény, amely a papok jövedelmi viszonyaival foglalkozott, ezek közül az 1909. évi XIII. törvénycikk a lelkészi jövedelem kiegészítéséről rendelkezett, az 1913. évi XXXVIII. törvénycikk pedig a lelkészi illetményeknek korpótlékok útján való emeléséról címet viselte, és a törvényesen bevett vallásfelekezetek lelkészei részére meghatározott feltételek és korlátok között az államkincstár terhére korpótlékot engedélyezett.

Időrendben a következő az 1913. évi XXXV. törvénycikk volt, amely a hajdúdorogi görög katolikus püspökségről rendelkezett, és kimondta, hogy a hajdúdorogi görög katolikus egyházmegyének felállítása ezennel törvénybe iktattatik és ezen egyházmegyének mindenkori püspöke a förendiházi tagság jogával ruháztatik fel.

Szintén nagyobb jelentőségü a törvények sorában az 1916. évi XVII. törvénycikk az iszlám-vallás elismeréséröl, amely deklarálta, hogy az iszlám vallás törvényesen elismert vallásnak nyilváníttatik. 1917. évi IX. törvénycikk ismét a papság vagyoni viszonyait érintette, amikor családi pótlékot adott a lelkészeknek, ha jövedelmük nem ért el egy bizonyos összeget.

Az ezt követő események igen változatosak, mind 1918 forradalmi hulláma, mind a Horthy-korszak, majd az 1949-es népköztársasági alkotmánnyal elindított folyamat, de ezek már nem tartoznak a dualizmus témaköréhez.

Így jutunk el fokozatosan a rendszerváltás korszakáig, amely a szabadságjogok kiteljesedését vonja majd maga után.

\section{Irodalomjegyzék}

Balogh Margit: Egyházak és felekezetek. Egyházak a dualizmus korában. A kisegyházak és a magyarországi iszlám. In Kollega Tarsoly István (föszerk.): Magyarország a XX. században. II. kötet. Szekszárd, Babits, 1997a. 289. Online: https://mek.oszk.hu/02100/02185/html/244.html

Balogh Margit: Egyházak és felekezetek. 19. századi előzmények. In Kollega Tarsoly István (föszerk.): Magyarország a XX. században. II. kötet. Szekszárd, Babits, 1997b. 287. Online: http:// mek.niif.hu/02100/02185/html/236.html

Balogh Margit: Egyházak a dualizmus korában. Egyházak és felekezetek. In Kollega Tarsoly István (főszerk.): Magyarország a XX. században. II. kötet. Szekszárd, Babits, 1997c. 289. Online: https://mek.oszk.hu/02100/02185/html/237.html

Balogh Zsolt - Gárdos-Orosz Fruzsina: Vallásszabadság és lelkiismereti szabadság. In Halász Iván (szerk.): Alkotmányjog. Budapest, Dialóg Campus, 2018. 242-244. Online: www.uni-nke.hu/document/uni-nke-hu/Hal\%C3\%A1sz\%20Iv\%C3\%A1n\%20(szerk.).pdf

Boros Zsuzsanna - Szabó Dániel: A főrendiház. In Boros Zsuzsanna - Szabó Dániel: Parlamentarizmus Magyarországon (1867-1944). Parlament, pártok, választások. Budapest, ELTE Eötvös, 2014. Online: https://regi.tankonyvtar.hu/hu/tartalom/tamop425/2011_0001_527_parlamentarizmus/ch04s02.html 
Csizmadia Andor: A vallás- és lelkiismereti szabadság és a felekezetek egyenjogúságának kérdése Magyarországon a dualizmus korában. Jogtudományi Közlöny, 18. (1963), 1. 24-33. Online: http://real-j.mtak.hu/2217/1/JogtudomanyiKozlony_1963.pdf

Deák Ferenc: A vallás ügyében. A vallásbeli sérelmekről. In Deák Ferencz beszédei. I. kötet, 1829-1847. (Összegyüjtötte Kónyi Manó), Budapest, Franklin-Társulat Magyar Irod. Intézet és Könyvnyomda, 1882. Online: https://mek.oszk.hu/02200/02213/html

Deák Ferenc: Képviselőházi beszéd az állam és egyház viszonyáról Pest, 1873. június 28. A dualizmus évei 1869-1873. In Deák Ferenc: Válogatott politikai írások és beszédek. II. kötet, 1850-1873. Budapest, Osiris, 2001. Online: www.arcanum.com/hu/online-kiadvanyok/Deak-deak-ferenc-munkai-8751/deak-ferenc-valogatott-politikai-irasok-es-beszedek-6973/ii-kotet-18501873-7510/xi-fejezet-a-dualizmus-evei-1869-1873-81B6/kepviselohazi-beszed-az-allam-es-egyhaz-viszonyarol-pest-1873-junius-28-82BA/

Eötvös József: A vallás befolyása az államra. In Eötvös József: A XIX. század uralkodó eszméinek befolyása az Államra. II. kötet. 230-236. Online: http://mek.oszk.hu/06600/06619/pdf/19_szazad2.pdf

Gróf Széchenyi István beszédei. II. kötet. Budapest, Athenaeum, 1887. Online: https://mek.oszk. hu/16300/16374/16374.pdf

Horváth Attila: A vallásszabadság és az egyházjog története Magyarországon az államalapítástól a II. világháborúig. Hét Hárs, 10. (2011), 3-4. 12-20. Online: http://real.mtak.hu/34851/7/vallasszabadsag_es_egyhazjog_tortenete_magyarorszagon.pdf

Katus László: Vallások, egyházak. In Egyháztörténet. Budapest, Enciklopédia Humana Egyesület, 2000. Online: https://mek.oszk.hu/01900/01903/html/index5.html

Kútfők. 304. szám. (1907) A Református Papi Kongresszus állásfoglalása az 1848: XX. T.-Cz. végrehajtása tárgyában és gróf Apponyi Albert vallás és közoktatásügyi miniszter nyilatkozata és Tisza István beszéde ugyanebben az ügyben. Magyar-Zsidó Szemle, 24. (1907), 2. 390-395. Online: www.epa.uz.ua/01800/01891/00008/pdf/mzssz_1907_04_390-395.pdf

Niklai Patrícia Dominika: Az 1855. évi osztrák konkordátum - ahogyan az egyház látta. Ars Boni, 2015. október 11. Online: https://arsboni.hu/az-1855-evi-osztrak-konkordatum-ahogyan-azegyhaz-latta/

Trefort Ágoston: Emlékbeszédek és tanulmányok. Budapest, A M. Tud. Akadémia KönyvkiadóHivatala. 1881. Online: http://real-eod.mtak.hu/1450/7/MTA_Konyvek_131021_000870770.pdf

Zakar Péter: Kossuth Lajos egyházpolitikai elvei a reformkorban. Acta Academiae Paedagogicae Agriensis Nova Series: Sectio Historiae, (2002), 129-141. Online: http://publikacio.uni-eszterhazy. hu/2936/1/129-141_Zakar.pdf

\section{Jogforrások}

1790/91. évi XXXVIII. törvénycikk a zsidókról

1790/91. évi XXVII. törvénycikk a görög nem-egyesült vallásuakról

1848. évi XX. törvénycikk a vallás dolgában

1867. évi XII. törvénycikk a magyar korona országai és az Ő Felsége uralkodása alatt álló többi or-

szágok között fenforgó közös érdekü viszonyokról, s ezek elintézésének módjáról

1867. évi XVII. törvénycikk az izraeliták egyenjogúságáról polgári és politikai jogok tekintetében

1868. évi IX. törvénycikk a görög-keleti vallásuak ügyében

1868. évi XLIV. törvénycikk a nemzetiségi egyenjogúság tárgyában

1868. évi LIII. törvénycikk a törvényesen bevett keresztyén vallásfelekezetek viszonosságáról 
1885. évi VII. törvénycikk a förendiház szervezetének módositásáról

A vallás- és közoktatásügyi magyar kir. ministernek 55.711/1892. szám alatt valamennyi tankerületi

kir. főigazgatósághoz intézett rendelete

1894. évi XXXI. törvénycikk a házassági jogról

1894. évi XXXII. törvénycikk a gyermekek vallásáról

A vallás- és közoktatásügyi ministernek 1675/1895. eln. számú rendelete

1894. évi XXXIII. törvénycikk az állami anyakönyvekről

1895. évi XLII. törvénycikk az izraelita vallásról

1895. évi XLIII. törvénycikk a vallás szabad gyakorlásáról

A vallás- és közoktatásügyi, a belügyi és az igazságügyi m. kir. ministerek 1896. évi 56/V. K.

eln. szám alatt kelt rendelete

1909. évi XIII. törvénycikk a lelkészi jövedelem kiegészitéséről szóló 1898. évi XIV. törvénycikk módositásáról

1913. évi XXXV. törvénycikk a hajdudorogi görög katholikus püspökségről

1913. évi XXXVIII. törvénycikk a lelkészi illetményeknek korpótlékok utján való emeléséről

1916. évi XVII. törvénycikk az iszlám-vallás elismeréséről

1917. évi IX. törvénycikk az 1917/18. költségvetési év első négy hónapjában viselendő közterhekről és fedezendő állami kiadásokról

1993. évi XXXI. törvény az emberi jogok és az alapvető szabadságok védelméről szóló, Rómában, 1950. november 4-én kelt Egyezmény és az ahhoz tartozó nyolc kiegészítő jegyzőkönyv kihirdetéséről

Az Európai Unió Alapjogi Chartája 